\title{
Review of 'Pastoralism and common pool resources - rangeland co-management, property rights and access in Mongolia', by Sandagsuren Undargaa
}

Jane Addison

\author{
Book details \\ Sandagsuren Undargaa \\ Pastoralism and common pool resources - rangeland co-management, property rights and access in Mongolia \\ Hardcover: 272 pages \\ Publisher: Routledge; 1 edition (April 11, 2016) \\ Language: English \\ ISBN-13: 978-1138847484; ISBN-10: 1138847488
}

Keywords: Human geography, Political economy, Common property, Institutions, Access

Since Hardin's influential treatise on the tragedy of the commons, scholars and practitioners have placed institutional drivers of social and environmental change at the heart of natural resource management and development initiatives. Significant institutional reforms to address resource decline have emerged. The potential for nested governance systems with common property institutions at their base have been given particular attention. However, about 25 years after dryland Mongolia's transition to a market-driven economy, the ways in which institutions serve, and fail to serve, the pastoral economy and resources upon which it is based are still contested.

In the newly published book, Pastoralism and common pool resources - rangeland co-management, property rights and access in Mongolia, author Undargaa 'puts property in its place'. Using Mongolia as a case study, Undargaa highlights the inability of contemporary institutional theories to adequately recognize other production components of the mobile pastoral economy, such as labour and livestock. In doing so, she brings a fresh perspective to the Mongolian literature in this space and, perhaps more importantly, maps out potential

Correspondence: jane.addison@jcu.edu.au

James Cook University/CSIRO Land and Water, 1 James Cook Drive, Townsville 4810, Australia

(c) The Author(s). 2017 Open Access This article is distributed under the terms of the Creative Commons Attribution 4.0 International License (http://creativecommons.org/licenses/by/4.0/), which permits unrestricted use, distribution, and reproduction in any medium, provided you give appropriate credit to the original author(s) and the source, provide a link to the Creative Commons license, and indicate if changes were made. 
highlights the way in which the production components of labour, land and livestock have been controlled and accessed through different socio-political periods. In doing so, she maintains that until relatively recently, access to, and the utilization of, these three capitals have been controlled in a more synergistic manner than they are today. As an example, during Mongolia's feudal period, monastic and princely lords had exclusive rights and control over large-scale human migration patterns and livestock as taxable property, with resource access rules at the micro-level being managed between herders. In effect, livestock were the primary and exclusive resource of these lords, with the control of labour and land the means by which this resource could be built. In contrast, contemporary pastoral institutions reflect a conservation agenda by primarily focusing in on access to land, with this agenda constrained by, for example, local governments being unable to control the internal migration of herders and their livestock. Undargaa argues that the crafting of institutions that regulate only one or two of these three production components has produced many of the unexpected and undesirable outcomes that the pastoral economy now experiences.

The first chapter embeds the work theoretically, justifies the book's main premise, introduces the case study area and lays out the chapters. Chapter 2 sets the scene. The impacts of twentieth century colonialism on resource use and the development trajectories of Inner Asia and Africa are outlined, particularly in regard to mobile pastoralism. Undargaa effectively includes these histories to build the case that common property rules and principles can be almost impossible to apply in practice, especially when it comes to crafting institutions for natural resource management.

Chapters 3 to 6 provide an institutional overview of mobile pastoralism, centring on Mongolia, through different time periods. Chapter 3 covers the pre-collective period (1206 to 1921); chapter 4, the collective period (1921-1991); and chapter 5, the period of the transition to a market economy (primarily the 1990s). It is not immediately clear how historical institutional structures governing access to the resources of labour, land and livestock relate to modern day natural resource management. However, through these chapters, Undargaa uses historical precedence to build a case for her argument that control over all three of these capitals is necessary to the pastoral economy.

By chapter 6, the post 1990s period, the implications of not systematically and synergistically controlling all three capitals become obvious. Undargaa argues that a lack of control on livestock and labour by the government, intersecting with stronger institutional control over some aspects of access to land, has resulted in problems such as elite capture, conflict between herders and overgrazing. Chapter 6 focuses in on the modern state's attempts, and subsequent failures, to regulate the pastoral economy, as well as that of more recent players: domestic and international non-government organizations. Undargaa's use of case study data, embedded throughout her chronological account, is particularly strong in this chapter and the next. In chapter 6, for example, she uses this data to illustrate the inherent institutional disconnect between the responsibility of local ( $b a g$ ) leaders to regulate pasture use, their legal inability to regulate the location of registered winter shelters (which is legislated for at the higher order soum level) and the inability of both lower order officials to regulate the migration of new herders and their livestock into their area of management, with freedom of movement guaranteed in Mongolia's constitution. She goes on to illustrate some of the strategies by which herders respond to or exploit these institutional disconnects: at times relatively benignly in the form of a retreat to precollective informal institutions and at other times by the exploitation of networks with those in a position of power for personal gain.

Chapters 7 and 8 explore the modern emergence and re-emergence of community-based NRM, and reserve pasture areas, the former driven by international theories of common property resources. In critiquing the newer model of community-based NRM herder groups collectively regulating their own pasture use, Undargaa asserts that 'national and international policy advisors examine the common property dilemma only within the western orientated exclusive property rights concept' (p. 163). She interrogates this model by highlighting the historical relationships between formal and informal institutions around migration, livestock production support and use and exclusive rights of possession for different parts of the production system (e.g. livestock, forage, land, winter shelters and the pasture itself), her basic premise being that pastoral production is about more than simply the right to access pasture.

Chapter 8's focus on the re-emergence of reserve pasture areas is one of a variety of 'home-grown' initiatives that is rarely examined in the published literature and is thus an interesting inclusion. The chapter provides a contrast to chapter 7's focus on community-based NRM, highlighting the Mongolian government's preference for supporting pastoral livelihoods and risk management via centralized, Ulaanbaatar-driven policy reform. The case study of the reserve pasture area is thus a salient one, suggesting that the pastoral economy's institutional challenges may have more complex drivers than the simple import of prescriptive institutional theories, an implication that could be more deeply explored in the future.

Undargaa's thesis, as well as being of general theoretical interest, is timely in her country of interest. The 
'property rights' issue in Mongolia continues to be highly political, with inappropriate institutional design accused of being the root cause of significant herder-to-herder conflict and overgrazing-mediated land degradation. By providing solid evidence of institutional misfits, this book reveals the structures and processes that may help. Undargaa concludes the book (chapter 9) by mapping out potential ways forward for pastoral institutions in Mongolia. She calls for a stronger focus on the integrated management of production components and pasture, particularly via the strengthening of pre-existing formal institutions at the local level. Throughout the book, Undargaa provides a very strong dataset and theoretical justification for such a position. Importantly, the position is one that may be implementable in the current institutional context.

\section{Acknowledgements}

I would like to acknowledge James Cook University and CSIRO Land and

Water for providing in-kind resources for this review.

Competing interests

The author declares that she has no competing interests.

\section{Publisher's Note}

Springer Nature remains neutral with regard to jurisdictional claims in published maps and institutional affiliations.

Published online: 01 December 2017

\section{Submit your manuscript to a SpringerOpen ${ }^{\mathcal{O}}$ journal and benefit from:}

- Convenient online submission

- Rigorous peer review

- Open access: articles freely available online

- High visibility within the field

- Retaining the copyright to your article

Submit your next manuscript at $\gg$ springeropen.com 